\title{
Further observations on MDT blister-calendar packs in vertical leprosy eradication programmes-a multicentre study (Phase II)
}

\author{
C. R. REVANKAR, ${ }^{*} \S$ NIVEDITA GUPTA,$\dagger$ \\ BIRTE H. SORENSEN, $\uparrow$ S. S. NAIK $+\&$ \\ MULTICENTRE STUDY GROUPף \\ *Bombay Leprosy Project, 11 VN Purav Marg, Chunabhatti, \\ Bombay 400 022, India; $\dagger D A N I D A-D A N L E P, F-42$, South Exten- \\ sion-I, New Delhi 110 039, India; and $\ddagger R R E$ Society, Acworth \\ Leprosy Hospital, Wadala, Bombay 400 031, India
}

Accepted for publication 18 January 1993

\begin{abstract}
Summary To improve operational efficiency as well as to improve patient compliance in leprosy programmes, DANIDA introduced blister-calendar packs (BCP) to deliver MDT in 4 MDT districts in India in 1987. An objective study (Phase II) involving 343 patients in a trial group (BCP group) and 253 patients in a control group (loose drug group) showed no significant difference in compliance rates for self-administered doses between the 2 groups.

Hence, while assessing the use of BCPs in leprosy programmes, other operational benefits like safe storage, easy transportation, easy drug accounting and safe preservation at home are to be considered. These aspects were followed up from Phase I of the study.
\end{abstract}

\section{Introduction}

An important factor that ensures the success of the MDT programme is obtaining maximum treatment compliance, especially for self-administered drugs. Many factors influence patients' compliance, including a continuous and regular supply of all 3 drugs and easy methods of preserving these drugs at home without damage or loss. Drug delivery in a socially acceptable and attractive form is an additional factor that influences patients' compliance. Easy storage, ease of transportation without any loss or damage, easy accounting and preparation for clinics at control unit level are also factors that could influence the efficiency of the MDT programme in general.

DANIDA is assisting the National Leprosy Eradication Programme (NLEP) in India in 4 districts, with 1 unit in Orissa, 1 in Tamilnadu and 2 in Madhya Pradesh. As an

$\S$ The study was done by the first author during his assignment with DANIDA-DANLEP, New Delhi.

- B. L. Sharma, P. R. Mangalani, S. L. Gupta, G. P. Mishra, S. L. Gude, A. Swamy, S. N. Satpathy, S. B. Patnaik, T. N. Swaminathan, T. D. Pandian. 
alternative strategy of drug delivery, to overcome the operational problems and to improve patients' as well as programme workers' compliance, we introduced BCPs (which are manufactured by Pharmanova AS Copenhagen) to all MB and PB patients, with the objectives described in an earlier paper on Phase I of this multicentre study. ${ }^{1}$

The Phase II trial was designed to study the patients' compliance for self-administered drugs of MDT by comparing patients in the same locality who received blister calendar packs with patients who received loose drugs. The study was carried out between 1987 and 1989.

\section{Material and methods}

MDT is delivered through a circuit plan, as described by NLEP, India. ${ }^{2}$ (A circuit consists generally of 2 subcentres with 2 paramedical workers (PMW) who serve a population of 40,000.) We selected 8 subcentres randomly from 4 districts which have been entered into the MDT programme-Salem district in Tamilnadu state, Cuttack district in Orissa state, and Durg and Rajnandagaon districts in Madhya Pradesh state. In each circuit, a single subcentre was selected for the trial group (BCP), while the other was selected for the control group (loose drugs).

All the MB and PB patients of both sexes were included from these subcentres except patients under 14 and over 50 years of age, as their compliance is likely to be influenced by other factors, such as parents administering drugs to their children and older patients being helped by other family members. The customary visits (Preclinic motivation visit) usually made to remind the patients of the day pulse clinics were held did not take place in these subcentres to eliminate the influence of the paramedical workers' visits.

Patients who attended regularly for the monthly supervised pulse dose were visited once every 2 months by the paramedical worker in charge of the sector for tablet/capsule count and for collection of urine samples for the DDS test without a prior warning. Urine samples were collected at home on 3 occasions, at 2 monthly intervals, 7 days after the last pulse dose and 7 days before the next pulse dose. The tablet/capsule count took place at the time of urine collection. The urine samples were coded and sent to RRE Society, Bombay, for performing a quantitative test $^{3}$ (Dapsone/Creatinine ratio) as well as a qualitative test (Tile Test method). ${ }^{4}$ The results were decoded at the end of the study.

- The result was considered positive or regular by quantitative test when the Dapsone/ Creatinine ratio ranged between 17.8 and 135.0 on an intake of $100 \mathrm{mg}$ dapsone daily. ${ }^{5}$

-The qualitative test was considered positive when the urine was pink. ${ }^{4}$

- The tablet/capsule count was considered 'Correct' when the number of dapsone tablets/clofazimine capsules on the day of the count tallied with the date of issue.

- Tablet/capsule count was considered 'Wrong' when the number of dapsone tablets/ clofazimine capsules remaining on the day of the count did not tally with the date of issue.

The paramedical workers, non-medical supervisors and medical officers were given intensive training in the field to carry out this study effectively. A simple data collection form was designed to feed data into the computer at the DANLEP office, New Delhi. 


\section{Results and Discussion}

Table 1. Number of leprosy patients in the study

\begin{tabular}{llll}
\hline & \multicolumn{3}{c}{ No. of patients } \\
\cline { 2 - 3 } Group & MB & PB & Total \\
\hline Trial & 197 & 367 & 564 \\
Control & 187 & 266 & 453 \\
\hline
\end{tabular}

A total of 1017 adult male and female patients were included in this study. However, due to operational problems, urine samples could not be collected from all the patients on 3 occasions at regular intervals in the routine leprosy eradication programme.

On all 3 occasions, no significant difference was observed between trial and control groups regarding their compliance for intake of self-administered drugs. The compliance rate ranged between $86-94 \%$ in the trial group and $83-95 \%$ in the control group.

Dapsone tablet/clofazimine capsule results were available from all the 564 patients in the trial group and from 453 patients in the control group for the 3 occasions. The tablet/ capsule counting method was followed to observe compliance for self-administered drugs. The compliance rate ranged between $86-91 \%$ in the trial group and $87-89 \%$ in the control group. No significant difference was observed between the 2 groups. All these patients were regular for monthly supervised pulse doses throughout the 6 months of the study period.

In DANIDA MDT districts, other intervention techniques such as community participation were also attempted to improve the compliance rate for drug intake. This may have contributed to the compliance of both the study and control groups.

A similar study was undertaken in an urban area where no other interventions such as community participation were undertaken in order to improve compliance rates. The results did not show any significant difference between patients using BCPs and loose

Table 2. Compliance rate by urine test method*

\begin{tabular}{|c|c|c|c|c|c|c|}
\hline \multirow[b]{2}{*}{ Frequency } & \multicolumn{3}{|c|}{ Trial group } & \multicolumn{3}{|c|}{ Control group } \\
\hline & Total & Positive & Negative & Total & Positive & Negative \\
\hline I & $\begin{array}{c}343 \\
\%\end{array}$ & $\begin{array}{r}296 \\
86\end{array}$ & $\begin{array}{l}47 \\
14\end{array}$ & $\begin{array}{c}253 \\
\%\end{array}$ & $\begin{array}{r}209 \\
83\end{array}$ & $\begin{array}{l}44 \\
17\end{array}$ \\
\hline II & $\begin{array}{c}265 \\
\%\end{array}$ & $\begin{array}{r}250 \\
94\end{array}$ & $\begin{array}{r}15 \\
6\end{array}$ & $\begin{array}{c}164 \\
\%\end{array}$ & $\begin{array}{r}141 \\
86\end{array}$ & $\begin{array}{l}23 \\
14\end{array}$ \\
\hline III & $\begin{array}{c}134 \\
\%\end{array}$ & $\begin{array}{r}126 \\
94\end{array}$ & $\begin{array}{l}8 \\
6\end{array}$ & $\begin{array}{l}55 \\
\%\end{array}$ & $\begin{array}{l}52 \\
95\end{array}$ & $\begin{array}{l}3 \\
5\end{array}$ \\
\hline
\end{tabular}

* By quantitative and qualitative test of urine samples. 
Table 3. Compliance rate by tablet/capsule count method

\begin{tabular}{|c|c|c|c|c|c|c|}
\hline \multirow[b]{2}{*}{ Frequency } & \multicolumn{3}{|c|}{ Trial } & \multicolumn{3}{|c|}{ Control } \\
\hline & Total & Correct & Wrong & Total & Correct & Wrong \\
\hline I & $\begin{array}{c}564 \\
\%\end{array}$ & $\begin{array}{r}484 \\
86\end{array}$ & $\begin{array}{l}80 \\
14\end{array}$ & $\begin{array}{c}453 \\
\%\end{array}$ & $\begin{array}{r}396 \\
87\end{array}$ & $\begin{array}{l}57 \\
13\end{array}$ \\
\hline II & $\begin{array}{c}564 \\
\%\end{array}$ & $\begin{array}{r}488 \\
87\end{array}$ & $\begin{array}{l}76 \\
13\end{array}$ & $\begin{array}{c}453 \\
\%\end{array}$ & $\begin{array}{r}401 \\
89\end{array}$ & $\begin{array}{l}52 \\
11\end{array}$ \\
\hline III & $\begin{array}{c}564 \\
\%\end{array}$ & $\begin{array}{r}515 \\
91\end{array}$ & $\begin{array}{r}49 \\
9\end{array}$ & $\begin{array}{c}453 \\
\%\end{array}$ & $\begin{array}{r}399 \\
88\end{array}$ & $\begin{array}{l}54 \\
12\end{array}$ \\
\hline
\end{tabular}

drugs. ${ }^{6}$ It therefore could be inferred that apparently BCP does not improve patients' compliance.

However, Phase I of this study (performed in the same 4 districts) showed that patients receiving BCPs preferred them to loose drugs because, for example, the BCPs are attractive and easier to handle, carry and preserve. Similarly leprosy control unit field workers reported that BCP was easier to prepare for clinics, and to dispense and transport the drugs and to prepare monthly drug accounting lists. The time required to prepare a pulse clinic for between 50 and 100 patients was less than 1 hour with BCPs but was about 3-5 hours with loose drug counting and packing.

Thus, while evaluating the use of BCPs in mass leprosy eradication programmes, it would be advisable to consider the operational advantages of this alternative system of drug delivery.

BCPs may be even more useful for integrated leprosy control programmes where primary health care personnel (such as medical officers and multipurpose workers) are involved in drug delivery. Staff working in these programmes would value a simple and quick method of drug delivery and drug accounting.

\section{Acknowledgments}

The authors wish to thank the Government of India and the State Health authorities for permitting DANIDA-DANLEP to deliver MDT through blister-calendar packs. Our thanks are also due to the medical and paramedical personnel and patients of Cuttack, Durg, Rajnandagaon and Salem districts for their co-operation during the multicentre study. The authors also thank Mr P. Radhakrishnan and Mrs Samruddhi S. Ghosalkar of the Bombay Leprosy Project for secretarial assistance.

\section{References}

${ }^{1}$ Revankar CR, Sorensen Birte H, Kielstrup RW, Multicentre Study Group. Delivery of MDT through blistercalendar packs in leprosy eradication programmes - multicentre field study (Phase I). Lep Rev, 1989; 60: 135.

2 Government of India, Guidelines for multidrug treatment in endemic districts 1986. Published by Leprosy Division, DGHS, New Delhi.

3 Ellard GA, Gammon PT, Harris JM. The application of urine tests to monitor the regularity of dapsone selfadministration. Lepr Rev, 1974; 45: 224. 
${ }^{4}$ Irudayaraj PS, Lourdumary, Aschoff M, Balkrishnan S. A comparison of screening tests for dapsone in urine. Lepr India, 1983; 55: 528.

5 Naik SS, Ganapati R. Regularity of dapsone intake by leprosy patients attending urban treatment centre. Lepr India, 1977; 49: 207.

${ }^{6}$ Revankar CR, Dhamale CB, Ganapati R. Experience of multi-drug therapy blistercalendar packs in an urban leprosy control programme in Bombay. Letter to Editor, Lepr Rev, 1991; 62: 336.

Lepr Rev (1993) 64, 250-254

\title{
Nouvelles observations sur le conditionnement de MDT sous emballage monoalvéo- laire daté dans les programmes verticaux d'éradication de la lèpre-une étude multicentrée (Phase II)
}

\author{
C. R. Revankar, Nivedita Gupta, Birte H. Sorensen, S. S. Naik et \\ Groupe D’Etude Multicentré
}

Résumé Pour améliorer l'efficacité opérationnelle des programmes contre la lèpre en même temps que l'observance du traitement par le patient, DANIDA a introduit les emballages à alvéoles datées (BCP) pour distribuer MDT dans 4 districts MDT des Indes en 1987. Une étude objective (Phase II) comprenant 343 malades dans un groupe d'essai et 253 dans un groupe témoin (drogue en vrac) n'a pas révélé de différence significative entre les deux groupes dans les taux d'observance pour les médicaments administrés par le malade lui-même.

Par conséquent, lorsqu'on évalue l'usage de BCP dans les programmes anti-lèpre, on doit considérer les autres avantages opérationnels, tels que sécurité du stockage, facilité du transport, facilité de la compatibilité du médicament et sécurité de la conservation à la maison. L'étude de ces aspects continue la Phase I du programme.

\section{Observaciones adicionales sobre los empaques blister-calendario en los programas verticales de eradicación de la lepra—un estudio multi-centro (Fase II)}

\author{
C. R. Revankar, Nivedita Gupta, Birte H. Sorensen, S. S. Naik y El \\ Grupo de Estudio Multi-Centro
}

Resumen Para mejorar la eficacia operativa además de mejorar la conformidad por los pacientes de los programas contra la lepra, DANIDA introdujo empaques blister-calendario (BCP) para realizar MDT en 4 distritos MDT de India, en 1987. Un estudio objetivo (Fase II) con 343 pacientes en un grupo de prueba (grupo BCP) y 253 pacientes en un grupo de control (grupo de droga al granel), no indicó una diferencia significativa de los niveles de conformidad para las dósis autoadministradas entre los dos grupos.

Por lo tanto, aunque evaluamos el uso de BCPs en los programas contra la lepra, se considerarán otros beneficios operativos como almacenamiento seguro, facilidad de transporte, control de la droga, y preservación segura en domicilio. Se continúan estos aspectos de la Fase I del estudio. 